\title{
HEARING TEACHERS AT THE PRIMARY SCHOOLS FOR THE HEARING IMPAIRED IN THE CZECH REPUBLIC AND THE IN DEAF CULTURE KNOWLEDGE
}

\author{
Pavel Kučera \\ Palacky University, Czech Republic
}

\begin{abstract}
When pupils with hearing impairment have hearing parents, the school for hearing impaired is usually the first institution where those students first encounter Czech sign language. That is why teachers should have information about Deaf culture, customs and history. Only then can a student with a hearing impairment become convinced that his language is full-fledged so he can be proud of it, as well as his Deaf culture. Teachers at Primary schools for the hearing impaired are supposed to be role models for pupils with hearing impairment and be one of the first people who are influencing them in this area. The aim of the research was to find out the level of Deaf cultural awareness of hearing teachers and whether they do know the customs and traditions of the Deaf. The research was conducted through the form of through structured interviews.
\end{abstract}

Keywords: Hearing teachers, Deaf culture, customs and traditions, sign language, specific needs of the deaf.

\section{Introduction to the Issue}

Deaf culture includes the Deaf with a capital „D” - the members of the cultural and linguistic minority of the Deaf. The basic characteristic of the Czech Deaf community is the communication in Czech sign language.

Members of the Deaf community are very appreciative of mutual contact and friendship. Bonds between deaf people are very strong. Deaf people love to spend time together and seek opportunities to communicate in their own language. The Deaf community forms its own little world, where people know each other, and communicate openly and directly. It has been known for deaf people to start talking to each other on the street, even if they have never met before or do not know each other - not only here in the Czech Republic but also abroad.

The development of Deaf culture occurs in the deaf clubs, where Deaf people meet at various events (such as balls, sport events, Witch burning, sign language production - Talking Hands, a charity concert Signed by Heart, benefit concert Twelfth Night, etc.). Deaf people have their art, which is primarily storytelling, funny stories, anecdotes and various games - humour is intended for entertainment within the community, where everyone share the same culture and language, theatrical performances of Deaf themselves (eg. theatre I Cannot Hear). 
In the deaf community, there are behaviour or etiquette rules for how to get one's attention by touching, how to interrupt a conversation between two people, attracting attention with the help of lights in the room, saying goodbye and so on). In the Deaf culture, thereare also certain ways of saying „Bon appetit!", making a toast with the touching of hands, "universal" greeting, greeting with kisses on the cheek, clapping which deaf people do by raising their hands and flapping them. Deaf media plays a very important role in the Deaf community such as Deaf magazines, movies and TV programmes for the Deaf.

Deaf people present themselves as a cultural and linguistic minority who considers itself to be equal with the majority of the population. However, deaf people need to compensate for their loss of hearing. As members of the cultural and linguistic minority, they claim the right to use a Czech Sign Language Interpreter. Deaf people are very much aware of how interpreters are irreplaceable and as a result, there are now higher requirements for them than in the past. Deaf people expect Czech sign language interpreters to follow the Code of Ethics for the sign language interpreters and to be professional at all times.

The autor considers believe that teachers at primary schools for the hearing impaired are supposed to be positive role models for Deaf pupils and be one of the first people to influence them in this area. If pupils with hearing impairment have hearing parents, school is usually the first place where they first encounter Czech sign language. Therefore teachers should have information about deaf people's culture, customs and history. Only then can a student with a hearingimpairment become aware that his language is full-fledged so he can be proud of it, as well as of his Deaf culture.

\section{Classification of communication systems for the Deaf}

Promoting sign languages is associated with extensive linguistic researches, dating back to the last century. In 1960, a publication called Sign Language Structure was published by an American linguist W. Stokoe, who demonstrated that sign languages carry the essential characteristics of natural languages. This was the basis for sign language linguistics and since 1970s, the US has seen rapid sign language linguistics development. In 1971, Gallaudet University built Stokoe's Language Research Laboratory where a number of research projects began resulting in a number of publications on American Sign Language. (Macurová, 2008)

The officially recognised communication systems of the deaf in the Czech Republic are defined by the Act no. 423/2008 Coll., which is the full text of Act no. 155/1998 Coll., on sign speech and about amending other laws, as follows from changes made by Law no. 384/2008 Sb. on Communication Systems of Deaf and Deaf-Blind individuals. (Zákon č 384/2008 Sb.)

Czech Sign Language is a communication system of a visual-motor nature. „Czech Sign Language is a natural and fully-fledged communication system 
formed by specific visual movement-based means, that is, by the shapes of the hands, their position and movements, facial expressions, the position of the head and upper part of the body. Czech Sign Language has the basic attributes of a language, that is sign-based communication, double structure, productivity, distinctiveness and historical dimension, and is stable from both lexical and grammatical perspectives. " (Zákon č 384/2008 Sb.)

\section{Communication systems in the educational process}

Communication systems used in the educational process of pupils at the schools for the hearing impaired at individual schools varies. We can say that during the educational period of individuals with hearing impairment, two basic communication streams were developed - audio oral and visual motoric (Horáková, 2012). Communication systems based on these two streams are used at particular schools, depends on the preferred approach to pupils with hearing impairment.There is the oral method approach, the total communication method approach and in recent years, also the bilingual approach.

\section{Cultural and linguistic context of hearing impairment}

The term deaf culture was established in the 1970s but of course, it was in existence much earlier. Deaf culture is maintained within the Deaf community. Its transmission is unique in the fact, that only $5-10 \%$ of the transmission is possible from generation to generation in the deaf family, because $90-95 \%$ of deaf childrenare born to hearing parents. Sharing mutual culture and transfer is later taking place at deaf schools, at boarding houses, in deaf organisations. (Kosinová, 2008)

Communication is the essence of existence of the deaf community and their culture. Among themselves, through their language, Deaf people can communicate fully, pass on their experience, humour, telling stories and legends to each other. Kannapell (in Wilcox, 1989) describes a very strong feeling of self-confidence and equivalence thanks to the smooth and easy communication with other Deaf people. Members of the Deaf community recognise sign language as their primary communication code. There are typical rules of deaf communication and certain specifications, which emerges from the visual motoric nature of the language. Eye contact, facial expressions and body posture all have a very important role to play. Communication is very direct and can differ greatly in the rules of behaviour, when greeting, wishing Bon Apetit, attracting attention and so on.

The identity of the deaf adult is understood as a consistent sense of self, „finding yourself”, an awareness of ,where I belong”, like the social aspect of identity and ,who I am”, as the personal aspect of identity. It is a developmental process that an individual's identity is formed gradually which depends on many factors - attitude towards the child's hearing impairment, communication at 
home and later in school, relationships with classmates and peers and also depends on whether there was identification deaf adult role model present during deaf pupil's development.

Part of Deaf culture is the Deaf art. Kosinová (2008) divides the Deaf art to folk art - telling fictional tales, short stories based on sign language - including $\mathrm{ABC}$ stories and stories with classifiers, humour - telling jokes or stories based on language, anecdotes - deaf people share their experiences on relationships with hearing people such as communication issues and classic misunderstandings, games - based on visual perception where deaf people welcome movement, logistic, visual or games based on sign laguage, visual arts - this can include painting, sculpture, architecture etc. containing information that is essential for deaf people; there are mostly deaf amateur artists, whose work has contributed to the cultural heritage of the Deaf, theatre theatre performances for deaf viewers are a great experience when translated into Czech sign language. Respectively Deaf actors have one of the main means for how they can implement themselves (the only professional deaf theatre company is Theatre I Cannot Hear); this includes pantomime (known czech deaf company Pantomima S.I.), Czech sign language poetry, interpretation of the songs in sign language.

\section{Deaf media}

Deaf media in the deaf culture not only adds magazines for the Deaf called Gong, Info-Zpravodaj. Some schools for the hearing impaired also publish their school magazines, as well as various DVD-ROMs, CD-ROMs related to deaf issues, their language and culture. Many makers of deaf related DVD-ROMs and CD-ROMs are themselves Deaf. Deaf people are also representated in the film sector - AWI film, fairy tales in Czech sign language on DVD-ROM and CD-ROMs; in television broadcasting, there are spaces for deaf people such as news in Czech sign language and Czech TV Deaf Club (both broadcasted by ČT2). There are also programmes supplied with closed captioning (which you can find on teletext page no. 888). A very important part of life today for Deaf people is information technology via the Internet (internet portals for the Deaf and about the Deaf). For example, in communication technology, there are systems for instant messaging (ICQ, Skype, MSN) and the use of SMS messages via the use of a mobile phone.

\section{The main aim of the research}

The aim of the research is to find out the level of Deaf culture awareness amonghearing teachers of the Deaf and whether they are aware of the customs and traditions of the Deaf. 
Partial aims of the research

- $\quad$ Find out the current situation regarding awareness and knowledge of Deaf culture in hearing teachers working at primary schools for hearing impaired in the Czech Republic.

- Focus on the relationship between hearing teachers and Czech sign language

- Determine whether hearing teachers know the rules of intercultural communication with Deaf people.

\section{The methodology and the research sample}

The method used was qualitative research, where data were obtained through a structured interview, which lasted $10-20$ minutes.

Questions used in the structured interview were based on information about Deaf culture, own experience and consultations with experts in the field.

The research was conducted from January 2014 to February 2015 with 8 from 13 primary schools for hearing impaired in the Czech Republic. I met with the hearing teachers in person, we discussed the questions and sometimes I added extra explanatory information.

The respondents to the research were hearing teachers working on a secondary level of primary schools for hearing impaired in the Czech Republic with the bilingual approach and the approach of philosophy of total communication.

The research involved 82 teachers $(100 \%)$, of which $68(83 \%)$ were female and 14 male $(17 \%)$. The age of most of the respondents was 34-45, of which there were 39 in this group. In the age group between $21-33$ years, there were 13 teachers and in the age group of $46-55$, there were 22 teachers and over 51 years, 8 teachers.

\section{Interpretation of the research results}

There were $62(72 \%)$ respondents studying courses in Higher education, with the remaining respondents still at university alongside his/her current job. We can conclude that the majority of the teachers satisfy the statutory requirements stated by law for elementary education. In the schools, $17(20,7 \%)$ teachers taught humanities, $58(70,7 \%)$ teachers taught sciences and $7(8,5 \%)$ taught technical or vocational subjects. When investigating how long the teachers were practising at primary schools for the hearing impaired, it is evident that the majority of teachers $39(47,6 \%)$ are amongthose with long years of experience, having worked for more than 18 years with pupils with hearing impairment. $19(23,2 \%)$ teachers worked for $11-18$ years in these schools. 15 $(18,3 \%)$ teachers had the shortest practice, from $1-5$ years. $9(11 \%)$ of the teachers worked in the education of hearing impaired pupils for $6-10$ years. 
From a total of 82 teachers, there were $8(9,8 \%)$ who used Czech sign language in the education of students with hearing impairment. $45(54,9 \%)$ respondents can partially communicate with deaf people whereas $29(35,4 \%)$ do not use Czech sign language at all. As follows from the survey, 7 (8,5\%) respondents with more than 10 years' teaching experience does not master the use of natural language of the Deaf.

On the question based on the knowledge of the difference between the use of Czech sign language and signed Czech answered correctly 67 (81,7\%) respondents, $3(3,7 \%)$ did not answer at all and $12(14,6 \%)$ did not know the difference between Czech sign language and signed Czech.

Deaf with a capital „D”, 28 (34,1\%) respondents answered correctly. The other $31(37,8 \%)$ respondents did not answer correctly. 23 (28\%) respondents did not even know there was a difference between the use of the small "d" and large ,D”.

On the question of whether the deaf are a cultural and linguistic minority, $39(47,6 \%)$ respondents answered positively, $43(52,4 \%)$ negatively. It is surprising that more than half of the teachers do not agree with the fact that Deaf people are seen as a cultural and linguistic minority. However, when asked about why they do not view Deaf people as a cultural and linguistic minority, the respondents describe them as a specific group,which has its own distinctive culture and language. They add that it's different in language because the Czech language belongs to the majority whereas sign language is a minority language. The respondents mention that there are differences in the culture, that deaf people declare values, customs, traditions which are different from the hearing world, and they are proud of their Deaf identity. Amongst the respondents, there were hearing teachers who also disagreed with the statement that Deaf people are a linguistic and cultural minority. On this issue, they still see the constant controversy as they do not perceive Deaf people as a minority but as disabled citizens. Although they admit that Deaf people have their own history, customs and specific behaviour, and communicate only by hands.

On the question of what is included in Deaf culture, 23 respondents said Czech sign language, 21 said signed Czech, 38 said Czech sign language simultaneously with spoken Czech language, 41 said specific standards of Deaf people's behaviour, 6 said that Deaf use to be late, 74 said deaf institutions/deaf clubs etc. and 47 said social events for the Deaf.

On the question whether Czech Sign Language is a fully-fledged language with natural language attributes, $32(39 \%)$ responded positively and the remaining $47(57,3 \%)$ respondents replied that it is not. $3(3,7 \%)$ of the respondents did not know that the Czech sign language is the natural language of the Deaf. Of the $32(39 \%)$ respondents who said that sign language is a fullfledged language with natural language attributes, I asked for an explanation. Only $11(13,4 \%)$ answered correctly, saying that the Czech sign language is like any other language in that it has its own rules, grammar, the basic attributes of a 
language, that issign-based communication, double structure, productivity, distinctiveness and historical dimension, specific signs, and is stable from bothlexical and grammatical perspectives. They also said that Czech Sign Language is accompanied by facial expression and non-manual means and cannot be written down.

On the question of whether Czech sign language is an international sign language, $77(93,9 \%)$ answered correctly with $5(6,1 \%)$ reporting an incorrect answer.

On the knowledge of the customs and traditions of the Deaf, $11(13,4 \%)$ respondents answered postively with the remaining 71 (86,6\%) not knowing the Deaf customs and traditions. Hearing teachers have very little knowledge of the customs and traditions of the Deaf and can only provide basic information. For example, Deaf events such as sport and cultural events like balls, their own humour, clapping the deaf way by the fluttering of hands, or greeting someone the deaf way by touching the faces.)

On the question of knowing famous people from the Deaf world, only 37 $(45,1 \%)$ knew someone, with the remaining respondents having no knowedge at all. When answering the question, many mentioned more names of the famous or well known deaf persons in the Czech Republic or abroad. The respondents stated these names - numbers in brackets states how many times these names were said: Petr Vysuček (29x), Věra Strnadová (25x), Helen Keller (18x), Josef Brožík (15x), Charles Michel de l'Epée (11x), Bedřich Smetana (9x), Zuzana Hájková (8x), Marie Basovníková (6x).

Magazines for the Deaf 69 (84,1\%) interviewees knew some, 13 (15,9\%) had no knowledge of magazines for the Deaf. All 69 respondents are aware of the magazine GONG, 17 respondents added magazine UNIE, 4 of them knew INFO-ZPRAVODAJ.

When asked about the number for the teletext page where Deaf people can turn captioned subtitles on, $64(78 \%)$ respondents gave the correct answer. Other respondents answered incorrectly and some could not remember.

Interviewees had to name a Deaf related documentary and $56(68,3 \%)$ respondents correctly indicated TV Deaf Club. The remaining respondents answered incorrectly and gave wrong programme names.

When asked about Institutions where Deaf native signers teach Czech sign language to the hearing public, $43(52,4 \%)$ respondents correctly stated a number of organisations (Pevnost, 3Dimenze, Trojrozmerr, Czech Union of the Deaf). $3(3,7 \%)$ respondents incorrectly stated Language Centre Ulita (Ulicentrum), 7 (8,5\%) respondents classified incorrectly Czech Chamber of Sign Language Interpreters and the remaining respondents did not know or did not remember.

When questioned about websites for/about the Deaf, 58 (70,7 \%) respondents were able to answer while $24(29,3 \%)$ did not know. Among the web addresses that were reported less frequently or occasionally, were included: 
www.helpnet.cz, www.neslysici.cz,www.ruce.cz, www.ticho.cz, www.asnep.cz, www.cktzj.com, www.frpsp.cz,www.csns.cz, www.cun.cz, www.appn.cz, www.snncr.cz, www.gong.cz, www.pevnost.com, www.spreadthesign.comand other websites like Deaf school websites.

When asked about which mistakes to avoid when communicating with Deaf people, 73 (89\%) teachers knew and $9(11 \%)$ did not know. Most of them were familiar with communication rules for the Deaf, the most considered were the most common and typical mistakes such as poor articulation, covering one's mouth when talking, turning their backs on Deaf people, rapid talking, sloppy pronunciation (which Deaf cannot lip read well), lack of eye contact and inappropriate or poor use of lighting - for example, dark room or bright light behind the person who is speaking which will make it very difficult for the deaf person to be able to lip-read.

Of the $82(100 \%)$ respondents to the question whether they felt it is important to have a Czech sign language interpreter for the Deaf, 77 (93,9\%) respondents answered positively, $2(2,4 \%)$ negatively and $3(3,7 \%)$ respondents did not give an answer. When asked why they felt it is important to have an interpreter, the vast majority of the respondents said it is essential for the Deaf person especially when communicating at the doctors, at council, in the court, in educational establishment, at social events and the theatre. When asked if they knew how they can book Czech sign language interpreter for the Deaf person, $26(31,7 \%)$ respondents answered correctly but $56(68,3 \%)$ did not know. They mentioned that the interpreter can be booked via the Czech Chamber of Sign Language Interpreters, or by phone (sending an SMS/text message to the phone number 776701 502) or e-mail via ASNEP. Respondents also had information about the possibility to book interpreter via the Centre providing Czech sign language interpreters for the Deaf, or know marginally that there is a possibility for an interpreter to be booked through the Czech Union of the Deaf or Association for the Deaf and Hard of Hearing in the Czech Republic.

\section{Conclusion and Solutions}

The research has shown how hearing teachers of the Deaf have very little information about Deaf people, their culture including their language, customs and history. Hearing teachers should not only have information about the mother tongue of deaf people but should also know about their culture, customs and history. Only then can a student with hearing loss be aware that sign language is full-fledged and he can be proud of it, as well as on his Deaf culture. It is very disturbing to think that hearing teachers do not realise that for a Deaf person, education in Czech sign language is absolutely vital. Only 8 of the teachers $(9.75 \%)$ who were interviewed, mastered Czech sign language. This number is alarming. Headmasters should consider including this fact into the acceptance criteria for a teacher of the Deaf - to have not only theoretical but also practical 
knowledge of Czech sign language as a means of communication of the Deaf. I am aware of the fact that not all pupils at schools for the hearing impaired are deaf and that there are also hard of hearing students including those with cochlear implants as well as others with multiple disabilities.

In education, the role of a teacher is irreplaceable. The teacher should not only have adequate educational knowledge, but also motivational and organisational skills to educate and generate new information, and should be responsible, reliable and have a positive attitude in his approach to work and towards to his students, natural authority and ability to get students' trust and so on. Courses for Special Education at the time of study at university should demonstrate how to communicate with Deaf pupils and students and approach them. The future teachers of the Deaf should not be missing information also on the social needs of people with hearing impairments, assistive technical aids as well as basic knowledge of Czech sign language and Deaf culture. They should be fully aware of the Deaf world, their history, their culture, how they live, communicate as well as to know about their customs, traditions and values.

Hearing teachers should be constantly educated both in their field of teaching as well as the field of Deaf people. They should bear in mind that through the natural language of the Deaf, hearing teachers are able to teach Deaf everything. Of course, we should keep in mind the importance of a positive role model, there should be employed also large number of hearing impaired teachers themselves so they can be cultural and identificational role models for Deaf pupils and students at the schools for the hearing impaired.

A surely good thing would be ifDeaf people themselves could create a Deaf manual as basic informative tool, from which the hearing teachers of the Deaf could refer to and use it as a basic course of information when referring to Deaf culture with specifics on rules of communication, customs and traditions as well as contacts with local Deaf associations, clubs and websites. Thanks to this manual, hearing teachers would be able to pass on those information to their hearing impaired pupils.

Most children with hearing impairment are born to hearing parents, so they would miss the chance of passing the Deaf culture from generation to generation (from parents to their children). But Deaf culture is able to pass on in Deaf schools and boarding schools among other deaf peers as well as in various organisations for the Deaf including Deaf clubs. Social values, customs, rules of conduct, awareness of the history and even language among themselves do not pass only from parents to children, but mostly fellow students at schools for the hearing impaired.

If there are hearing impaired teachers available at the school, it is very important role in the educational process. This way, Deaf children of Deaf parents are language role model or also those deaf adults which has positive effect on one's personality and creates the deaf identity. For the deaf child to develop and thrive, it is very important for him/her to experience and be exposed 
to native users of sign language and deaf culture bearers - deaf adults who are proud of their language and culture and who lead happy lives. The deaf child will then become confident in the knowledge that he/she can also grow to be someone who is successful and happy, despite being deaf. The small deaf child will then not be under the misunderstanding that he/she will become hearing once they have grown up.

This post is part of the Grant and is the partial results of the specific research project IGA PdF UP „Research selected deviations and failures communication skills focusing on the specifics of speech therapy and Hearing Impairment diagnosis and intervention" - PdF UP, 2015/2016, IGA_PdF_2015_024, researcher: Kateřina Vitásková

\section{References}

Horáková, R. (2012). Sluchové postiženi. Úvod do surdopedie. Praha: Portál, 160 s. ISBN 978-80-262-0084-0.

Kosinová, B. (2008). Neslyšící jako jazyková a kulturní menšina - kultura neslyšících. 2. opravené vydání. Praha: Česká komora tlumočníků znakového jazyka, 61 s. ISBN 97880-87153-94-9.

Kyle, J. (1998). Společenství Neslyšících: Kultura, zvyky, tradice. In Homoláč, J. (Eds.). Komunikace Neslyšícich. Sociolingvistika (antologie textů). Praha: FF UK, s. 141-150.

Macurová, A. (2008). Dějiny výzkumu znakového jazyka u nás a v zahraničí. Druhé opravené vydání. Praha: Česká komora tlumočníkủ znakového jazyka, 93 s. ISBN 978-80-8721800-6.

Wilcox, S. (1989). American Deaf Culture. Burtonsville: Linstok Press. 195 p. ISBN 0932130-09-7.

Zákon 384/2008 Sb. o komunikačnich systémech neslyšicich a hluchoslepých osob. [online]. [cit. 02.2.2015]. Dostupné na World Wide Web: <http://www.sagit.cz/pages/ sbirkatxt.asp? $z d r o j=s b 08384 \& c d=76 \&$ typ $=r>$. 